\title{
Identification and distribution of sibling species of Anopheles maculipennis complex (Diptera: Culicidae) in north-eastern Poland ${ }^{1}$
}

\author{
Beata KuBICA-BIERNAT* and Beata KOWALSKA-UlCZYŃSKA** \\ * Department of Tropical Parasitology, Institute of Maritime and Tropical Medicine, Medical University of Gdanisk, \\ Powstania Styczniowego 9B, 81-519 Gdynia, Poland; e-mail:bebe@gumed.edu.pl \\ **Academic Secondary School No. 1 in Gdynia, Poland
}

\begin{abstract}
A previously established species-diagnostic PCR assay was used to determine the species composition and distribution of sibling species of the Anopheles maculipennis complex in north-eastern Poland. which was historically affected by malaria. Of all the 1120 mosquitoes of An. maculipennis complex (1002 adults and 118 larvae) identified by molecular means, all were either An. messeae/daciae or An. maculipennis s. s. with the former dominant in all collection localities. Their halophilic sister taxon An. atroparvus. previously collected along the Baltic Sea coast was not found. New records of An. maculipennis s. s. and An. messeae were located in 9 UTM squares respectively and these species were new for Tuchola Forests (Bory Tucholskie) and for the district of Ilawa Lakeland (Pojezierze Itawskie). An. messeae is a new species also for Masurian Lakeland (Pojezierze Mazurskie).
\end{abstract}

Key words: Anopheles maculipennis complex, sibling species, species-diagnostic PCR, Poland

\section{INTRODUCTION}

Cryptic species complexes comprise groups of closely related species that are difficult sometimes impossible to distinguish by morphological alone. Many of the major Anopheline malaria vectors are members of such cryptic species complexes, which include both vector and non-vector species. Moreover, a few member species are often found sympatrically (Collins \& Paskewitz 1996).

Anopheles maculipennis Meigen 1818, the historical malaria vector in Europe, was first exposed as a species complex in the 1920's by Falleroni (1926) and van Thiel (1927) who described the sibling taxa An. messeae and An. atroparvis, respectively. The larval, pupal and adult stages of the component taxa in the Maculipennis Complex are morphologically similar to each other. However, most can be on the basis of egg shell patterns, although this is only useful when gravid females are captured. More recently, larval chaetotaxy, cytotaxonomic methods, cross breeding experiments, the use of enzyme electrophoresis and analysis of cuticular hydrocarbons, PCR methods and DNA sequencing have provided evidence for the existence of the different species in the complex (Kitzmiller et al. 1967, Munstermann \& Conn 1997).

Currently 11 species of the An. maculipennis s. 1. are recognized in the Palearctic Region: An. maculipennis s. s. Meigen, An. atroparvus van Thiel and An. messeae Falleroni, which occur also in Poland (Kubica-Biernat 1997, Okróy-Rysop 1991), An. artemievi Gordeyev, Zvantsov, Goryacheva, Shaikevich \& Yezhov. in Kyrgizstan (Gordeyev et al. 2005).

\footnotetext{
${ }^{1}$ This study was financially supported by the Polish State Committee for Scientific Research (KBN) no 6 P04C 01819
} 
An. melanoon Hackett in the southern Europe, An. labranchiae Falleroni, and An. sacharovi Favr in coastal areas along the Mediterranean Sea and the Black Sea, and An. beklemishevi Stegnii \& Kabanova, are distributed sympatrically with An. messeae in Sweden, Finland and European part of Russia (Ramsdale \& Snow 2000). An. persiensis Linton, Sedaghat \& Harbach has been described from Iran (Sedaghat et al. 2003), An. martinitus Shingarev, 1928 occur in northern Africa and middle Asia. White (1978) suggested that An. lewisi Ludlow may be synonymous with An. messeae or An. beklemishevi, but this nominal form is still regarded as a valid species because its identity has not been resolved. Recent molecular studies on the $A n$. maculipennis s. 1. in Romania revealed a new species, Anopheles daciae Linton, Nicolescu \& Harbach, (Nicolescu et al. 2004) which occurs also in England (Linton et al. 2005) and Poland (Wegner, personal communication in 2009) and probably in Italy, the Netherlands, former Yugoslavia and Kazakhstan (di Luca 2004). An. messeae and An. daciae are morphologically and genetically the most similar species in the Palearctic Maculipennis Complex. The nuclear ITS2 sequences of both species are the same length, differing by only five bases. These species cannot be differentiated using the current messeae-specific primers designed by Proft et al. (1999). It seems that the presence of An. daciae has been obscured by An. messeae across their extensive and seemingly sympatric ranges and could be responsible for malaria transmission (Nicolescu et al. 2004).

The distribution of malaria is determined by the occurrence of competent mosquito vectors, and the temperature requirements of the Plasmodium sp. for sporogony within the vector itself (Knap \& Myjak 2009). In Poland, as in many areas of central Europe, malaria was due to Plasmodium vivax was observed in the past. This parasite was transmitted almost exclusively by $A n$. atroparvus and $A n$. messeae. The latter, was involved in malaria transmission in eastern Europe and western Asia, while An. atroparvus played the most important role as a malaria vector in north-western Europe (Jetten \& Takken 1994).

In Poland, malaria was endemic in some areas during the years following World War I, especially in swampy lowlands. The disease reappeared at the end of World War II. Thus, more attention was paid again to the An. maculipennis complex, particularly to An. atroparvus and An. messeae, which were the main vectors in the country (Kubica-Biernat 2005). Although, the indigenous malaria has been eradicated, the number of infections in Poland is likely to increase with the growth of travel to endemic areas.

\section{MATERIAL AND METHODS}

\section{Mosquito collections}

Anopheline mosquitoes were collected from 1999 to 2002 in the voivodeships of Pomorskie, Warmińsko-Mazurskie and Podlaskie (north and north-eastern Poland). The 54 collection sites covered 22 of the 3.000 UTM (Universal Transverse Mercator) $10 \mathrm{~km}^{2}$ Poland.

Resting adult were collected from the walls and ceilings of human houses, farm buildings and cellars an Nabokov-Zeifert aspirator. Further specimens, were collected using $\mathrm{CO}_{2}$ traps and entomological nets. Moreover, the catches on human bait were done by means of an aspirator. Preimaginal stages were captured in water bodies using standard dippers. Then, the larvae of the $1^{\text {st }}, 2^{\text {nd }}$ and $3^{\text {rd }}$ instars and pupae were reared in the laboratory in breeders in order to obtain larvae of the $4^{\text {th }}$ stage and adults - forms with fully developed taxonomic features. Mosquitoes were sorted to An. maculipennis s. 1. based on larval or adult morphological characteristics according to the identification keys of Skierska (1971, 1977) and stored individually in $70 \%$ ethanol for later molecular identification. 


\section{DNA extraction, amplification and sequencing}

DNA was individually extracted, either larval portions or single legs of adults, by lysis in ammonium hydroxide $\left(\mathrm{NH}_{4} \mathrm{OH}\right)$ (Rijkpema et al. 1996). Lysates were stored at $-20^{\circ} \mathrm{C}$ for further investigation.

Specimens were individually identified using the previously developed species diagnostic PCR assay of Proft et al. (1999). All specimens were tested using individual PCRs for the identification of species previously detected in Poland.

Reactions containing the universal primer UN and one of the three species specific primers: AMA (An. maculipennis s. s.), AMS (An. messeae/daciae) and AAT (An. atroparvus) were used to amplify fragments of different length of the ITS2 region of the ribosomal DNA (410 bp, $305 \mathrm{bp}$ and $117 \mathrm{bp}$, respectively) (Proft et al. 1999). PCR reactions were carried out in a reaction mixture that contained: $2.5 \mu \mathrm{l}$ of DNA template, $5 \mathrm{U}(0.125 \mu \mathrm{l})$ Taq polymerase (Gibco), $2.5 \mu \mathrm{l}$ of $10 \times$ PCR reaction buffer (Gibco), $0.5 \mu \mathrm{l}$ of $50 \mathrm{mM} \mathrm{MgCl}_{2}$ (Gibco), $1.25 \mu 1$ of $2.5 \mathrm{mM}$ dNTPs mixture (MBI Fermentas), $1 \mu \mathrm{l}$ of $10 \mu \mathrm{M}$ universal primer (UN), $1 \mu 1$ of 10 $\mu \mathrm{M}$ species specific primer (AMA or AMS or ATT) and sterile double distilled water (DDW) was added to a total volume of $25 \mu \mathrm{l}$. Samples were incubated for $3 \mathrm{~min}$ in $94^{\circ} \mathrm{C}$ and then thermally cycled 35 times with DNA denaturation at $94^{\circ} \mathrm{C}$ for $30 \mathrm{~s}$, primer annealing at $55^{\circ} \mathrm{C}$ for $30 \mathrm{~s}$, and primer extension at $72^{\circ} \mathrm{C}$ for $1 \mathrm{~min}$, with a final extension of $7 \mathrm{~min}$ at $72^{\circ} \mathrm{C}$.

PCR amplification of the nuclear ITS2 region was carried out using primers $5.8 \mathrm{~F}$ and $28 \mathrm{R}$ (Collins \& Paskewitz 1996). The concentrations of the reactants were: $5 \mu$ DNA template,

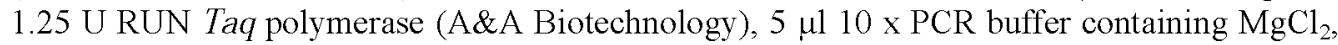
(A\&A Biotechnology), $5 \mu \mathrm{l}$ dNTPs mixture (MBI Fermentas), $1 \mu \mathrm{l}$ primers $10 \mu \mathrm{M}(5.8 \mathrm{~F}, 28 \mathrm{R}$ ) and DDW to a total volume of $50 \mu$. The samples were heated at $94{ }^{\circ} \mathrm{C}$ for $2 \mathrm{~min}$ before 35 cycles of amplification at $94{ }^{\circ} \mathrm{C}$ for $30 \mathrm{~s} \mathrm{min,} 53{ }^{\circ} \mathrm{C}$ for $30 \mathrm{~s}$ and $72{ }^{\circ} \mathrm{C}$ for $30 \mathrm{~s}$ followed by a final extension step of $10 \mathrm{~min}$.

All PCR reactions were carried out in Perkin Elmer GeneAmp PCR System 2400 and 9700 thermocyclers. Amplification products were visualised in 2\% agarose gels stained with ethidium bromide. Both positive and negative (sterile DDW) controls were run with each PCR reaction.

Amplicons of $5.8 \mathrm{~F}$ and $28 \mathrm{R}$ primers were purified by using the Clean-up purification kit (A\&A Biotechnology) and sequenced in both directions. DNA sequencing reactions were performed with the ABI PRISM 310 Genetic Analyser (Applied Biosystem). Sequences were edited and compared with representative gene sequences deposited in GenBank database using NCBI BLAST program (U.S. National Institute of Health, Bethesda, Maryland).

\section{Positive controls}

The DNA from morphologically and molecularly (ITS2 region sequence) verified samples of An. maculipennis s. s An. messeae and An. atroparvus served as positive controls. Bloodfed females of An. maculipennis s. s. and An. messeae were caught in the field and induced to lay eggs, which were then identified according to patterning of the eggs (Skierska 1971). Control of An. atroparvus (insectary strain) originated from Spain (courtesy Dr. Carlos Aranda Pallero, Consell Comarcal del Baix Llobregat).

\section{RESULTS}

Thirty six of the 54 prospected sites yielded samples of Anophelinae. In 18 of them only An. maculipennis s. 1. was noted, while in 11 captures stations it occurred together with $A n$. claviger s. 1. Moreover, the latter one was recorded in 7 locations where An. maculipennis s. 1. was absent. 


\section{Species identification based on ITS2 sequence}

Sixteen sequences were generated and identified to species based on similarity with the ITS2 sequences for members of An. maculipennis s. 1. available in GenBank. One sequence originated from Spain - it shows $100 \%$ homology with An. atroparvus (Z501102) from Italy, AM409779 from Russia, AF504248 from England and AY634530 from Romania.

Six sequences from Masurian (UTM: EF 41), Ilawa (CE 97) and Kashubian Lakeland (CF 23), Tucholskie Forests (CE 25), Białowieża Primeval Forest (FD 75) and Gdańsk (CF 42). They showed 100\% homology with sequences from GenBank: An. maculipennis s. s. AF342715 from Greece, Z50104 from Italy, FN665792 from Azerbaijan and from Germany (Proft et al. 1999) (not entered in GenBank).

Nine sequences from Masurian (UTM: EF 41), Ilawa (CE 97) and Kashubian Lakeland (CF 23), Tucholskie Forests (CE 25), Białowieża Primeval Forest (FD 73, 75), Żuławy (CF 41) and Gdańsk and vicinity (CF 42, 92), they showed 100\% homology with sequences An. messeae AF452699 from England, AF342711 from Greece, AF305556 from China, EF090191 from Romania and from Germany (Proft et al. 1999) (not entered in GenBank).

\section{Species diagnosis by PCR}

In total, 1.120 An. maculipennis s. 1. specimens were collected and identified by PCR, including 118 larvae (10.53\%) (Table 1). Two species were identified: An. messeae/daciae ( $\mathrm{n}=912$ specimens; 81.43\%) and An. maculipennis s. s. $(\mathrm{n}=208 ; 18.57 \%)$ (Table 1). No An. atroparvus were detected in these northerly collections sites. The majority of $A n$. maculipennis s. 1. specimens found $(\mathrm{n}=974)$ were collected in Pomorskie Voivodeship (Table 1). Amongst those, $81.52 \%$ were found to be An. messeae/daciae and $18.48 \%$ An. maculipennis s. $\mathrm{s}$.

Both species of the complex occurred in 19 and 15 collection sites, respectively, out of total 44 standings studied in this voivodeship. An. messeae/daciae was the dominant both among adults collected (84.35\%) and larvae (61.01\%). Moreover, it was the dominant species at all capture sites in the Podlaskie and Warmińsko-Mazurskie Voivodeships, where only adults were captured (Table 1).

Anopheles maculipennis s. 1. was noted in 26 localities, located in 17 squares of the UTM net. Eleven collection sites (in 6 UTM squares) were situated in urban areas (Table 1). Anopheles maculipennis s. 1. was reported in 107 UTM squares in Poland prior to this research, and herein $A n$. maculipennis s. 1. is reported in an additional 10 UTM squares for the first time (CF 13, 23, 41, 42, 92 \& CE 25, 97\& FD 73, 75 \& EF 41) (Fig. 1; Table 1).

In case of An. maculipennis s. s., during the present study its occurrence of was confirmed 12 UTM net squares of which 9 were new for this species (CF 13, 23, 41, 42, 92 \& CE 25, 97 \& FD 75 \& EF 41) (Fig. 2, Table 1).

The occurrence of Anopheles messeae/daciae was reconfirmed in 13 UTM squares in the present investigations, and new country records were established in a further 9 squares $-(\mathrm{CF}$ 23, 41, 42, $92 \&$ CE 25, $97 \&$ EF $41 \&$ FD 73, 75) (Fig. 3, Table 1).

\section{DISCUSSION}

Despite numerous publications concerning Culicidae in Poland, detailed information on the specific distribution of taxa within Anopheles sibling species complexes are still relatively poorly understood. Since the first record of Anopheles maculipennis complex in Poland at the end of $19^{\text {th }}$ century (as An. maculipennis, Nowicki 1873), only a few short reports and faunistic notes concerning its distribution have been published. Extensive study on malaria vectors 
carried out in the 1920-s showed that An. maculipennis s. 1. is very common in Poland (Tarwid 1934). Thus some 130 years later, although, An. maculipennis s. 1. has been reported 107 squares of UTM net (Kubica-Biernat 1999), knowledge of the distribution of component taxa was less clear. The result of our investigations added new distribution records of An. maculipennis s. 1. in 10 new UTM squares and reconfirmed another three UTM squares where it had been previously recorded. In the present study, specific identification of $A n$. maculipennis s. s., An. messeae/daciae and An. messeae have been confirmed in Poland, using PCR and sequencing of ITS2 region of nuclear DNA. Anopheles maculipennis s. s. is widely distributed in Europe and Asia, apart from Great Britain, Ireland, and the southern part of the Iberian peninsula. The distribution range of An. messeae covers the almost whole Europe and Asia, except Portugal and Spain, and this species occurs more frequently than An. maculipennis s. s. (Ramsdale \& Snow 2000).

Table 1. Occurrence of Anopheles maculipennis s. s. and An. messeae/daciae in the study areas

\begin{tabular}{|c|c|c|c|c|c|}
\hline \multirow{2}{*}{ UTM net square and collection site } & \multicolumn{2}{|c|}{ An. maculipennis s. s. } & \multicolumn{2}{|c|}{ An. messeae/daciae } & \multirow{2}{*}{ Total } \\
\hline & adults & larvae & adults & larvae & \\
\hline \multicolumn{6}{|c|}{ Pomorskie Voivodeship } \\
\hline CE 25 Kasparus & 6 & 0 & 41 & 0 & 47 \\
\hline CE 97 Dzierzgoń & 26 & - & 56 & - & 82 \\
\hline CF 07 Brzyno & 76 & - & 207 & - & 283 \\
\hline CF 13 Pomieczyńska Huta & 8 & - & 19 & - & 27 \\
\hline CF 23 Kielno & - & - & 3 & - & 3 \\
\hline CF 32 Gdańsk-Klukowo & - & 13 & - & 9 & 22 \\
\hline Gdańsk-Rębiechowo & - & 3 & 1 & 6 & 10 \\
\hline CF 33 Banino & - & 17 & - & 17 & 34 \\
\hline Gdańsk-Owczarnia & 1 & 2 & - & 4 & 7 \\
\hline CF 34 Gdynia-Wiczlino & - & 1 & - & 2 & 3 \\
\hline CF 35 Gdynia-Pierwoszyno & - & 2 & - & 1 & 3 \\
\hline CF 41 Radunica & - & 6 & 2 & 25 & 31 \\
\hline CF 42 Gdańsk-Migowo & - & 0 & - & 2 & 2 \\
\hline Gdańsk-Wrzeszcz & - & 0 & - & 2 & 2 \\
\hline Gdańsk-Siedlce & 0 & 0 & 1 & 1 & 2 \\
\hline Gdańsk-Orunia Dolna & 1 & - & 2 & - & 3 \\
\hline CF 43 Gdańsk-Oliwa & - & 1 & - & 2 & 3 \\
\hline Sopot-Karlikowo & - & 1 & - & - & 1 \\
\hline CF 92 Krynica Morska & 0 & 0 & 6 & 1 & 7 \\
\hline Przebrno & 16 & 0 & 384 & 0 & 400 \\
\hline In sum $[\mathrm{n} / \%]$ & $134 / 13.76$ & $46 / 4.72$ & $722 / 74.13$ & $72 / 7.39$ & $974 / 100.0$ \\
\hline \multicolumn{6}{|c|}{ Podlaskie Voivodeship } \\
\hline FD 73 Piaski & & 0 & & 1 & 1 \\
\hline FD 74 Poryjewo & & 2 & & 7 & 9 \\
\hline Orzeszkowo & & 9 & & 30 & 39 \\
\hline FD 75 Dubiny & & 3 & & 4 & 7 \\
\hline Postolowo & & 12 & & 20 & 32 \\
\hline In sum $[\mathrm{n} / \%]$ & & $26 / 29.54$ & & $62 / 70.46$ & $88 / 100.0$ \\
\hline \multicolumn{6}{|c|}{ Warmińsko-Mazurskie Voivodeship } \\
\hline EF 41 Wesolowo & & $2 / 3.44$ & & $56 / 96.56$ & $58 / 100$ \\
\hline In total $[\mathrm{n} / \%]$ & & $208 / 18.57$ & & $912 / 81.43$ & $1120 / 100.0$ \\
\hline
\end{tabular}




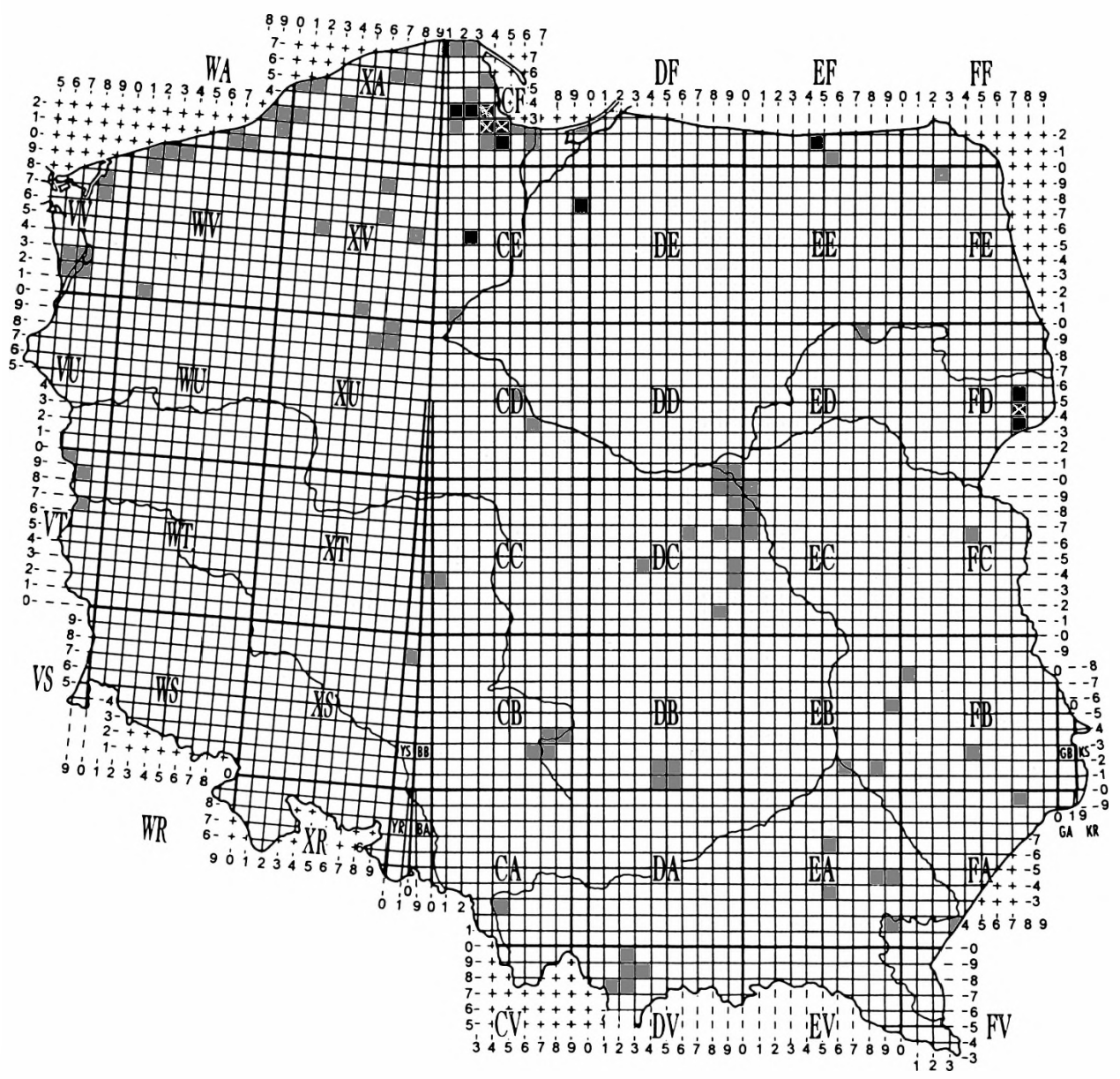

Fig. 1. Recorded distribution of Anopheles maculipennis s. 1. in Poland by UTM squares; grey squares - recorded distribution before present investigations (Kubica-Biernat 1999), black squares - recorded distribution in present investigations, black squares with white cross - recorded distribution in present and past investigations.

Although An. atroparvus has been reported in Poland in previous studies, it was not found in this survey. Although predominantly coastal, the first record of An. atroparvus was reported from Rokitnica village near the city of Bytom (CA48) (Weyer 1938), which remains the southernmost record of this species in Poland. Anopheles atroparvus was also captured in urban areas in the city of Gdańsk and its vicinity in many subsequent years (Lachmajer 1950, 1952, 1966, 1971, 1972, 1975, 1982, Skierska \& Szadziewska 1978). Maculipennis Complex specimens collected in the coastal regions of the in the 1940-s (Lachmajer 1948) showed high percentages of An. atroparvus (from $20 \%$ to $75 \%$ ). However, surveys on the western Baltic coast in 1963-1965 showed a significant reduction in prevalence, with An. atroparvus accounting for only $2.6 \%$ of the total "Maculipennis" Complex mosquitoes (Lachmajer \& Skierska 1968). Its presence was first reported in the mid-1980s in the coastal zone between Wejherowo \& Darłowo (Pomerania) (Okróy-Rysop et al. 1991). Similar studies carried out about the same time using the same methods revealed only An. maculipennis s. s. and An. 
messeae (Szadziewska \& Okróy-Rysop 1988, Wegner et al. 1993). The disappearance of An. atroparvus for Poland could be explained by the reduction of the brackish habitats favoured by An. atroparvus due to human intervention e.g., land reclamation, such as drainage of small reservoirs in urban or agriculture areas. However, as in other European countries, the targeted larvicide applications of the widespread malaria control measures in the 1940-s and 1950-s could have resulted in the decimation of An. atroparvus populations, whose niche was perhaps subsequently filled by An. messeae. A similar phenomenon was observed in The Netherlands, where in 1999, most anophelines collected were An. messeae (Takken et al. 2002). The authors concluded that the study area has undergone dramatic ecological changes since the earlier Anopheles surveys in 1935, causing the near extinction of An. atroparvus. Molecular identification of material collected by Lachmajer \& Skierska (1968) could be very informative in determining whether An. atroparvus was indeed still present at this time present, and in what proportion, relative to its sibling taxa.

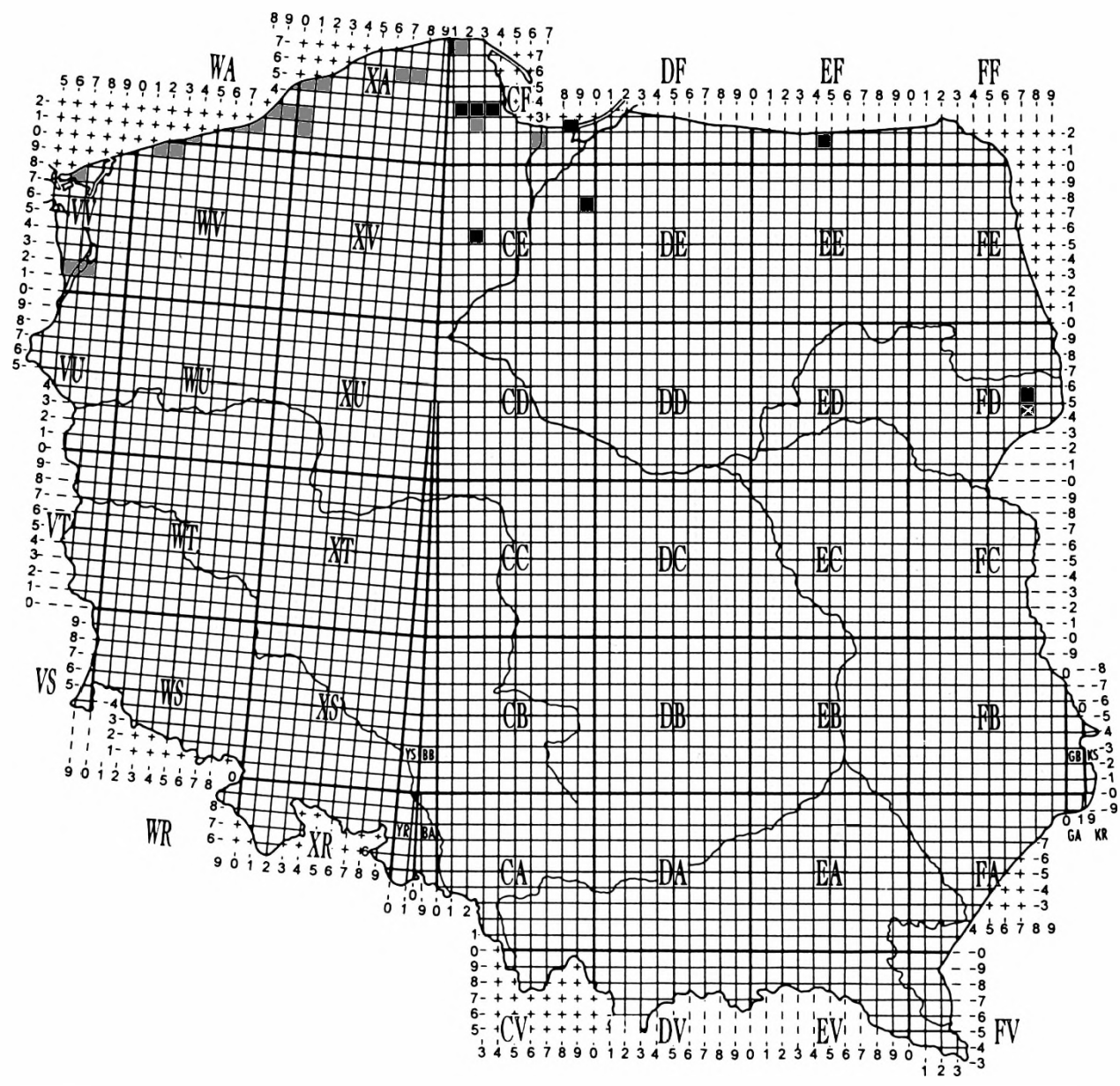

Fig. 2. Recorded distribution of Anopheles maculipenniss. s. in Poland by UTM squares. Legend: see Fig 1. 


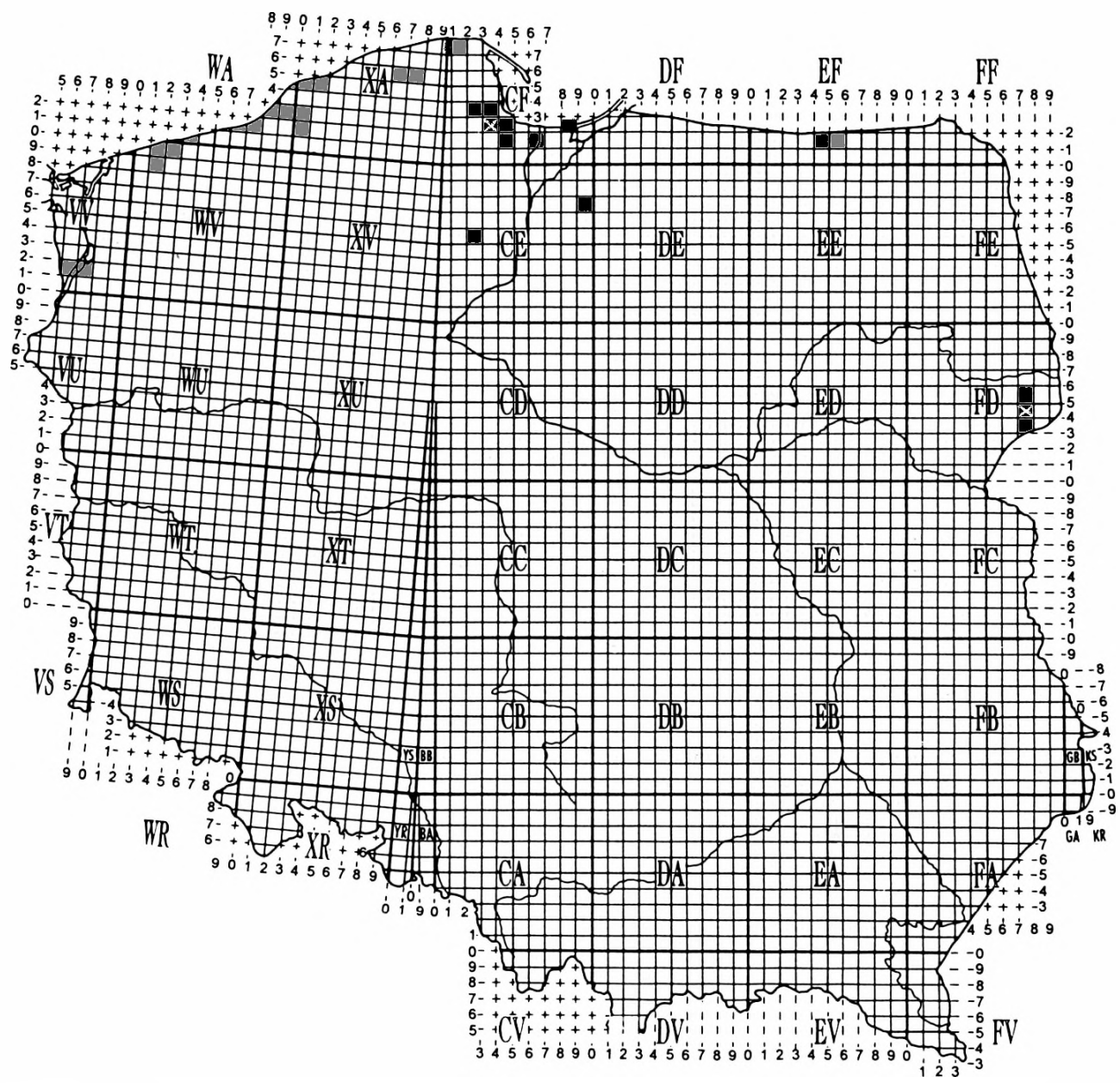

Fig. 3. Recorded distribution of Anopheles messeae/daciae in Poland by UTM squares.. Legend: see Fig. 1. UTM squares: CE 97, CF 23, 41, 42, 92, EF 41, FD 73, 75 - An. messeae identified using sequencing ITS2

An. messeae/daciae was almost 4 times as prevalent than An. maculipennis s. s. Domination of An. messeae/daciae was observed both in the Pomorskie Voivodeship (76.60\%), and in Podlaskie Voivodeship (70.46\%), in agreement with the results previously reported by Lachmajer \& Skierska (1968). The area of the Hel Peninsula is the exception, as in the end of the 1940-s An. atroparvus was documented as the most numerous species, comprising more than 75\% of Maculipennis Complex taxa collected in the region (Lachmajer 1948). The results of investigations from the 1980-s and early 1990s showed that in the area of the western Baltic coast, the occurrence of An. messeae (49.3\%) was comparable to An. maculipennis s. s. (48.5\%), whilst that of An. atroparvus was significantly lower (2.2\%) (Okróy-Rysop et al. 1991). On the other hand, in the Żarnowieckie Lake environs, An. messeae was significantly more dominant (72.33\%) than An. maculipennis s. s. (27.67\%), and An. atroparvus was not reported at all (Wegner et al. 1993). 
In the Pomerania Voivodeship, present study showed new records of Anopheles maculipennis s. s. and An. messeae in 7 squares of the UTM net, which covers Żulawy Wiślane (CF 41), Kashubian Lakeland (CF 13,23) and in the urban areas of the city of Gdańsk (CF 42). In addition, the presence of both An. maculipennis s. s. and An. messeae were showed on Vistula Spit (CF 92), where only An. maculipennis complex was reported 50 years ago (Eukasiak 1959). Moreover, both species were also recorded, in the Tuchola Forests and Ilawa Lakeland for the first time (CE 25, CF 97).

Sack (1925) first reported An. maculipennis s. 1. from the Podlaskie Voivodeship, but was unable to distinguish between the sibling species. Sampling conducted in the Bialowieża Primeval Forest and its vicinity in the Podlaskie Voivodeship, showed a dominance of $A n$. messeae (69.32\%) over An. maculipennis s. s. as reported in the 1950 s there by Lachmajer \& Skierska (1958). New country records are herein shown for both species: An. maculipennis s. s. (UTM square FD 75) (Fig. 2) and An. messeae (FD73 \& FD75) (Fig. 3). Here we support the absence of An. atroparvus reported in Lachmajer \& Skierska (1958). In the Masurian Lakeland, in Mikołajki vicinity (EE 36), only An. maculipennis s. 1. was previously reported (Wojnarowicz 1960), and recent studies reported An. messeae only (KowalskaUlczyńska \& Giłka 2003). Herein we report An. maculipennis s. s. from Masurian Lakeland for the first time.

Following WWI, 15 mosquito species, including An. maculipennis s. 1. (Martini 1920) were reported the TriCity agglomeration, including Gdańsk, Gdynia \& Sopot. It is worth to stress the repeated records of occurrence of Anopheles maculipennis s. 1. in Gdynia, Sopot and Gdansk, especially An. messeae/daciae - the malaria vector in the typically urban areas - as their larvae were found in 11 different collection sites within towns, suggesting favourable habitats and suitable hosts still exist in these regions. Moreover, in a water reservoir close to the GdańskRębiechowo international airport, the appearance of larvae of both An. maculipennis s. s. and An. messeae/daciae was noted, with the latter again dominating. As this airport sometime serves countries where malaria is endemic, it is possible for the reintroduction of malaria to occur in Poland through. Malaria-infected mosquitoes entering our country on board incoming international flights. In summer months, mosquitoes may survive long enough to take a blood meal and transmit the disease. The surrounding environs is predominantly farmland where these exotic mosquitoes can find hosts, and suitable resting and breeding places, creating perfect conditions to establish a new foci of malaria in Poland. Furthermore, 37\% of 95 cases of imported malaria presented in the clinic of Institute of Maritime and Tropical Medicine in Gdynia, between 1984-1993, were due to Plasmodium vivax, the historical malarial parasite in Poland (Jaremin et al. 1993/1994).

The permanent presence of historical vectors of disease in connection with possibility importing pathogens like in The TriCity area, creates potential epidemiological problems. Although endemic malaria has disappeared in Poland, every year more than 20 cases of malaria are imported by tourists and other travelers from malaria endemic areas. This has increased the concern that reintroduction of malaria into Poland is a real danger. Climatic changes such as global warming and associated increased precipitation are expected to extend vector ranges and population sizes of some species, potentially increasing malaria transmission rates (Kuhn et al. 2002).

\section{ACKNOWLEDGMENTS}

Authors offer their thanks to Dr Yvonne-Marie Linton for her useful suggestions and corrections in the writing of this manuscript. 


\section{REFERENCES}

COLLINS F. H. \& PASKEWITZ S. M. 1996. A review of the use of ribosomal DNA (rDNA) to differentiate among cryptic Anopheles species. Insect Molecular Biology 5: 1-9.

DI LUCA M., BOCOLINI D., MARINUCCI M. \& ROMI R. 2004. Intrapopulation polymorphism in Anopheles messeae (An. maculipennis complex) inferred by molecular analysis. Journal of Medical Entomology 4: 582-586.

Gordeyev M. I., Zvantsov A. B., Goryacheva I. I., Shaikevich Y. V. \& Yezhov M. N. 2005. Description of the new species Anopheles artemievi sp. n. (Diptera: Culicidae). Meditsinskaia Parazitologiia i Parazitarnye Bolezni 2: 4 5.

JAREMIN B., NAHORSKI W., GOLJAN J., FELCZAK-KORZYBSKA I., GÓRSKI J., MYJAK P. \& KOTıOWSKI A. 1993/1994. Malaria as an occupational disease. Bulletin of the Institute of Maritime and Tropical Medicine in Gdynia 44/45 (1/4): 43-50.

JETTEN T. H. \& TAKKEN W. 1994. Anophelism without malaria in Europe - A review of the ecology and distribution of the genus Anopheles in Europe. Wageningen Agricultural University Papers 94: 1-68.

KITZMTLLER J. B., FRIZZI G. \& BAKER R. H. 1967. Evolution and speciation within the maculipennis complex of the genus Anopheles. In: PAL R. \& WRIGHT J. W. (eds), Genetics of insect vectors of disease, pp 151-200. Elsevier, Amsterdam, 794 pp.

KNAP J. P. \& MyJaK P. (eds). 2009. Malaria w Polsce i na świecie: wczoraj i dziś. a-medica Press, Bielsko-Biała, 246 pp.

KOWALSKA-UlCZYŃSKA B. \& GEKA, W. 2003. Komary (Diptera: Culicidae) miejscowości Wyskok na Mazurach. Wiadomości Entomologiczne 22 (2): 91-100.

KuBiCA-Biernat B. 1997. Culicidae. In: RAZowski J. (ed.): Checklist of Animals of Poland, Vol. 5, Part 24, p. 178 Polish Academy of Sciences, Institute of Systematics and Evolution of Animals, Kraków: 260 pp.

KuBICA-BIERNAT B. 1999. Distribution of mosquitoes (Diptera: Culicidae) in Poland. European Mosquito Bulletin 5: 1-17.

KuBICA-BIERNat B. 2005. Malaria i jej wektory w Polsce. In: BUCZEK A. \& BŁASZAK C., (eds), Stawonogi różnorodność form i oddziaływań, pp. 281-287, Koliber, Lublin, 374 pp.

Kuthn K. G., Campbetl-Lendrtum D. H. \& Davies C. R. 2002. A Continental Risk Map for Malaria Mosquito (Diptera: Culicidae) Vectors in Europe. Journal of Medical Entomology 39 (4): 621-630.

LACHMAJER J. 1948. Rasy gatunku Anopheles maculipennis Mg. występujące na wybrzeżu (rok 1947/48). Przegląd Epidemiologiczny 2 (1/2): 133-136.

LACHMAJER J. 1950. Biologia Anopheles maculipennis atroparvus van Thiel na Wybrzeżu (1949/1950r.). Przegląd Epidemiologiczny 4: 1-37.

LACHMAJER J. 1952. Warunki zimowania samic Anopheles maculipennis atroparvus. Biuletyn Państwowego Instytutu Medycyny Morskiej i Tropikalnej w Gdańsku 4 (1): 79-96.

LACHMAJER J. 1966. Wrażliwość na DDT larw rodzaju Anopheles Meigen pochodzących z kilku miejscowości nadmorskich w latach 1961-1965. Bulletin of the Institute of Maritime Medicine in Gdansk 17 (1/2): 35-42.

LACHMAJER J. 1971. Host selection by Anopheles atroparvus v. Thiel 1927 (Diptera: familia Culicidae) in Gdańsk environment. Bulletin of the Institute of Maritime Medicine in Gdańsk 22 (1/2): 41-42.

LACHMAJER J. 1972. Investigation of changes in tolerance to DDT and dieldrin of female Anopheles labranchiae atroparvus v. Thiel (Diptera, Culicidae) in the Gdansk region. Bulletin of the Institute of Maritime Medicine in Gdańsk 23 (3/4): 171-181.

LACHMAJER J. 1975. Sezonowe zmiany w dynamice populacji larw Anopheles labranchiae atroparvus v. Thiel, 1927 w okolicach Gdańska. Wiadomości Parazytologiczne 21 (2): 175-189.

LACHMAJER J. 1982. Trophic connections of the Anopheles genus females in the vicinities of Gdansk. Bulletin of the Institute of Maritime and Tropical Medicine in Gdynia 33 (1/2): 71-80.

LACHMAJER J. \& SKIERSKA B. 1958. Niektóre dane o Anopheles maculipennis Meig. w Białowieży. Przegląd Epidemiologiczny 2: 185-192.

LACHMAJER J. \& SkIERSKA B. 1968. Biting mosquitoes (Diptera, Culicinae) found in the Baltic coastal area between the Vistula and Odra mouth, in the years 1963-1965. Bulletin of the Institute of Maritime Medicine in Gdańsk 19 (1/2): 7-20.

LINTON Y-M., LEE A. S. \& CURTIS C. 2005. Discovery of a third member of the Maculipennis Group in SW England. European Mosquito Bulletin 19: 5-9.

LUKASIAK J. 1959. Agresywne komary z terenu Krynicy Morskiej, woj. Gdańskiego. Wiadomości Parazytologiczne 5 (1): $25-27$.

MARTINI E. 1920. Uber Stechmucken besonders deren europaischen Arten und ihre Bekampfung. Archiv fur Schiffs und Tropenhygiene 24: 1-259.

MunstermanN L. E. \& CONN J. E. 1997. Systematic of mosquito disease vectors (Diptera, Culicidae): impact of molecular biology and cladistic analysis. Annual Review of Entomology 42: 351-369.

Nicolescu G., Linton Y-M., Vladimirescu A., Howard T. M. \& HaRbach R. E. 2004. Mosquitoes of the Anopheles maculipennis group (Diptera; Culicidae) in Romania, with the discovery and formal recognition of a new species based on molecular and morphological evidence. Bulletin of Entomological Research 94: 525-535.

NowICKI M. 1873. Beitrage zur Kenntnis der Dipterenfauna Galiziens. Krakau: 35 pp.

OKRóy-RYsop G. 1991. Culicidae. In: RAZOWSKI J. (ed.), Checklist of Animals of Poland, Vol. 2, Part 32, pp. 89-90. Ossolineum, Kraków: 342 pp.

OKRÓY-RYSOP G., WEGNER Z. \& STAŃCZAK J. 1991. Komary (Diptera: Culicidae) znalezione w pasie przymorskim od Wejherowa do Darłowa. Wiadomości Parazytologiczne 37: 45-51. 
PROFT J., MAIER W. A. \& KAMPEN H. 1999. Identification of six sibling species of the Anopheles maculipennis complex (Diptera: Culicidae) by polymerase chain reaction assay. Parasitological Research 85: 837-843.

RAMSDALE C. \& SNOW K. 2000. Distribution of the genus Anopheles in Europe. European Mosquito Bulletin 7: 1-17.

RiJkPEMA S. D., GOLUBiĆ D., MOLKENBOER M., VERBEEK-DE KRTIF N. \& SCHELLEKENS J. 1996. Identification of four genomic groups of Borrelia burgdorferi sensu lato in Ixodes ricinus ticks in a Lyme borreliosis region of northern Croatia. Experimental and Applied Acarology 20: 23-30.

SACK P. 1925. Beitrage zur Natur und Kulturgeschichte Lithauens und angrenzender Gebiete. Die Zweiflugler des Urwaldes von Bialovies. Munchen. Verlag der Bayer. Akademie Den Wissenschaften. Supplement 6 (9): $259-277$.

Sedaghat M. M., Linton Y.-M., Oshagi M. A., Vatandoost H. \& Harbach R. E. 2003. The Anopheles maculipennis complex (Diptera: Culicidae) in Iran: molecular characterization and recognition of a new species. Bulletin of Entomological Research 93: 527-535.

SKIERSKA B. 1971. Klucze do oznaczania owadów Polski. XVIII. Muchówki - Diptera. 9a. Komary - Culicidae. Larwy i poczwarki. PWN, Warszawa: 138 pp.

SkIERSKA B. 1977. Klucze do oznaczania owadów Polski. Postacie dojrzałe. XXVIII. Muchówki - Diptera. $9 \mathrm{~b}$. Komary - Culicidae., PWN, Warszawa: 120 pp.

SKIERSKA B. \& SZADZIEWSKA M. 1978. Early changes of density and specific structure of mosquitoes (Diptera; Culicidae) found in buildings in riverside villages situated near the mouth of the Vistula. Bulletin of the Institute of Maritime and Tropical Medicine in Gdynia 29 (1/2): 99-114.

SZADZIEWSKA M. \& OKRÓY-RYSOP G. 1988. Research on parasitic arthropods of the Lake Żarnowieckie environs, conducted out in 1981-1985. II Part: Mosquitoes (Diptera, Culicidae). Bulletin of the Institute of Maritime and Tropical Medicine in Gdynia 39 (3-4): 215-226.

TAKKEN W., GEENE R., ADAM W., JETTEN T. H. \& VAN DER VELDEN J. A. 2002. Distribution and Dynamics of Larval Populations of Anopheles messeae and A. atroparvus in the delta of the Rhine and Meuse, The Netherlands. A Journal of the Human Environment 31 (3): 212-218.

TARWID K. 1934. Résultats de 1'enquête de M. le Dr. H. Raabe sur les moustiques domestiques in Pologne en 1924 et 1925. Fragmenta Faunistica 2 (19): 161-179.

WEgner Z., KUBICA-BIERNAT B., STAŃCZAK J. \& RACEWICZ M. 1993. Badania faunistyczno-ekologiczne nad hematofagicznymi muchówkami prowadzone w okolicach Jeziora Żarnowieckiego w latach 1988-1991. I. Komary (Diptera: Culicidae). Biuletyn Metodyczno-Organizacyjny Instytutu Medycyny Morskiej i Tropikalnej w Gdyni 26: 55-72.

WEYER F. 1938. Die geografische Verbreitung der Rassen von Anopheles maculipennis in Deutschland. Zeitschrift für Parasitenkunde 10: 429-463.

WHITE G.B. 1978. Systematic reappraisal of the Anopheles maculipennis complex. Mosquito Systematics 10: $13-44$.

WoJNarowicz J. 1960. Culicinae larvae of small ponds. Polskie Archiwum Hydrobiologii 8: 183-221.

\section{STRESZCZENIE}

\section{[Identyfikacja i rozprzestrzenienie kryptogatunków Anopheles maculipennis s. I. (Diptera: Culicidae) w pólnocno-wschodniej Polsce]}

Celem niniejszej pracy byla identyfikacja kryptogatunków Anopheles maculipennis s. 1. na wybranych terenach północno-wschodniej Polski - niegdyś endemicznych terenach występowania malarii. Ogółem odłowiono przy użyciu standardowych dla rodziny Culicidae metod połowów i przebadano metodą PCR 1120 komarów z kompleksu Anopheles maculipennis: 1002 imagines i 118 larw. Stanowiska odłowu $(n=54)$ (obory, zabudowania mieszkalne, „wolna przyroda” oraz zbiorniki wodne) byly rozlokowane na terenie północnej Polski, w województwach: Pomorskim, Podlaskim i Warmińsko-Mazurskim i zlokalizowane w obrębie 22 kwadratów siatki UTM. Nie stwierdzono w niniejszych badaniach An. atroparvus - halofilnego gatunku charakterystycznego dla wybrzeża Bałtyku, notowanego przez szereg lat głównie na Wybrzeżu Gdańskim. Na całym badanym terenie gatunkiem dominującym byl An. messeae/daciae - glówny wektor Plasmodium vivax w Europie środkowo-wschodniej. Stwierdzono nowe stanowiska występowania An. maculipennis s. s. i An. messeae zlokalizowane w obrębie 9 kwadratów UTM, przy czym w Borach Tucholskich i na Pojezierzu Ilawskim wykazano te dwa gatunki po raz pierwszy, jak również pierwszy raz wykazano An. maculipennis s. s. na Pojezierzu Mazurskim. 